\title{
Impeded Thrips Transmission of Defective Tomato spotted wilt virus Isolates
}

\author{
Tatsuya Nagata, Alice K. Inoue-Nagata, Marcel Prins, Rob Goldbach, and Dick Peters
}

First author: EMBRAPA/Hortaliças, C. Postal 218, 70359-970, Brasília, DF, Brazil; second author: EMBRAPA/CENARGEN, C. Postal 2372, CEP 70770-900, Brasília, DF, Brazil; and third, fourth, and fifth authors: Department of Virology, Wageningen Agricultural University, Binnenhaven 11, 6709 PD, Wageningen, the Netherlands.

Accepted for publication 11 January 2000.

\begin{abstract}
Nagata, T., Inoue-Nagata, A. K., Prins, M., Goldbach, R., and Peters, D. 2000. Impeded thrips transmission of defective Tomato spotted wilt virus isolates. Phytopathology 90:454-459.

Two defective RNA-containing isolates (Pe-1 and 16-2) and an envelopedeficient $\left(\mathrm{env}^{-}\right)$isolate of Tomato spotted wilt virus (TSWV) were tested for their transmissibility by Frankliniella occidentalis. The Pe-1 isolate contained a truncated L RNA segment that barely interfered with symptom expression and replication of the wild-type (wt) L RNA segment. This isolate was transmitted with an efficiency of $51 \%$, a value comparable to that found for wt TSWV (54\%). Isolate 16-2, which contained a genuine defective interfering L RNA as concluded from its ability to suppress wt

L RNA synthesis and attenuation of symptom expression, was not transmitted at all. The midguts of all larvae that ingested Pe-1 became infected, whereas limited midgut infections were found in $24 \%$ of the larvae that ingested 16-2. This difference in infection could be explained by the presence of a low number of infectious units in the inoculum ingested from plants as demonstrated in infection experiments and verified by northern blot analysis. The env ${ }^{-}$isolate failed to infect the midgut after ingestion and could not be transmitted by any thrips stage. This isolate also cannot infect primary thrips cell cultures. Taken together, these results suggest that the envelope of TSWV contains the determinants required for binding and subsequent infection of thrips cells.
\end{abstract}

Tomato spotted wilt virus (TSWV), the type species of the genus Tospovirus in the family Bunyaviridae (17), is transmitted by thrips, a group of minute insects. Thus far, eight thrips species have been reported as vectors $(15,28)$, of which Frankliniella occidentalis is the most efficient one (29). The competence of thrips to transmit tospoviruses shows some unique features. They are acquired by young larval stages (27) and transmitted by larvae at the end of their second instar stage and by adults after a latent period during which the virus replicates $(25,30,31)$. Replication of TSWV in thrips has also been demonstrated in primary cell cultures of $F$. occidentalis and Thrips tabaci (19). The ability to acquire virus decreases with the development of the larvae and is completely lost when the thrips becomes an adult $(24,27)$. Hence, ingestion of virus by adults does not lead to transmission. The decreasing ability to become viruliferous is apparently caused by the development of an age-dependent midgut infection barrier $(18,24)$.

Two distinct types of TSWV mutants, generated during multiple mechanical passages in plants, have been described (21). One type contains defective RNAs that are generated by a single deletion in the polymerase-encoding L RNA segment $(8,10,21,22)$. Most of the isolates containing defective RNAs cause symptom attenuation in plants and represent true defective interfering (DI) RNAs. Some defective RNAs, however, hardly interfere with the synthesis of L RNA (8). The location of the deleted region in the L RNA varies but always occurs internally, preserving both termini of the molecule $(10,22)$. The second type of mutants is characterized by the failure to produce viral envelopes. Although lacking the viral envelopes, and hence the viral glycoproteins, these mutants are able to infect plants $(7,21)$.

Corresponding author: D. Peters; E-mail address: Dick.Peters@ medew.viro.wau.nl

Publication no. P-2000-0315-01R

(C) 2000 The American Phytopathological Society
In this paper, results on the acquisition and transmission of virus by thrips as well as infection of thrips by both types of TSWV mutants are reported. For this study, two defective RNA-containing isolates (Pe-1 and 16-2) $(8,10)$, of which only 16-2 contained a true DI RNA, and an envelop-deficient ( $\left.\mathrm{env}^{-}\right)$isolate (21) were selected. The ability of these mutants to infect thrips larvae after acquisition was analyzed using the whole mount immunofluorescent staining technique (WMIS) (18) and inoculation to thrips primary cell cultures (19).

\section{MATERIALS AND METHODS}

Mutant virus isolates. The wild type (wt) of the Brazilian TSWV isolate BR-01 $(2,3)$ and two of its derived lines containing defective L RNAs (Pe-1 and 16-2) were used in this study. They were generated by repeated mechanical passage of BR-01 wt on Capsicum annuum (Pe-1) or Nicotiana rustica (16-2) $(8,10)$. An envelop-deficient line of the Dutch TSWV isolate NL-04 (env-) (21) and its wt (NL-04 wt) were also included in the current study. Contaminating defective L RNA species were eliminated from the env ${ }^{-}$isolate by single local lesion isolation using Chenopodium quinoa plants as shown by northern blotting (Fig. 1). The presence or absence of defective L RNA species in the isolates used was verified by northern blot hybridization prior to and after transmission tests.

Enzyme-linked immunosorbent assay (ELISA). To use systemically infected Datura stramonium leaves with identical levels of virus titers for acquisition, their relative amount of virus was determined by double-antibody sandwich-ELISA using anti-nucleocapsid $(\mathrm{N})$ protein (3). Leaf disks of $5 \mathrm{~mm}$ in diameter were triturated in $0.01 \mathrm{M}$ potassium phosphate buffer, $\mathrm{pH} 7.2$, containing $0.14 \mathrm{M} \mathrm{NaCl}$ and $0.05 \%$ Tween-20 (phosphate-buffered saline [PBS]$\mathrm{T}$ ) in a ratio of $1 \mathrm{mg}$ of leaf material per $\mathrm{ml}$ of PBS-T. This ratio was used to avoid saturation of the antigen-antibody reaction (8).

Thrips rearing and virus acquisition. A Dutch population of F. occidentalis (NL3) (27) was reared in glass jars on bean pods. 
Cultures were incubated in a climate chamber at $25^{\circ} \mathrm{C}$ with a $16-\mathrm{h}$ photoperiod. Newborn larvae, up to $4 \mathrm{~h}$ old, were given an acquisition access period of $16 \mathrm{~h}$ on TSWV-infected $D$. stramonium leaves in Tashiro cages $(20,23)$ and then transferred to cages with healthy D. stramonium leaves. Samples of these larvae at 24, 72, and $96 \mathrm{~h}$ postacquisition (pa) during their larval development, or of 4- to 5-dayold adults after determining their transmission ability, were collected for WMIS (18).

Virus transmission assay. The transmission efficiency of thrips was tested using a petunia leaf disk assay (30). Newly emerged adults were individually placed on a petunia leaf disk in an Eppendorf tube for 2 days at $25^{\circ} \mathrm{C}$. The disks were then transferred to wells in a 24-well plate and incubated for 3 days floating on $2 \mathrm{ml}$ of tap water for the development of local lesions.

WMIS of thrips midguts. To detect and locate virus infection in the midgut, WMIS was performed essentially as previously described (9). Briefly, midguts of dissected thrips were mounted on an object glass coated with $0.5 \%$ poly-L-lysine, fixed with cold acetone, and incubated in PBS with $10 \%$ bovine serum albumin (BSA) for $1 \mathrm{~h}$ to block nonspecific binding of antibodies. Polyclonal antibodies against the viral nucleoprotein $(2 \mathrm{mg} / \mathrm{ml})$ were used as a first overlay for $2 \mathrm{~h}$ in $10 \%$ BSA-PBS. Prior to its use, this antiserum had been cross-absorbed with an extract from uninfected thrips (10\% [weight/volume] in PBS) and fractionated on a DEAESephacel column (Sigma Chemical Co., St. Louis). After washing the specimens with PBS, the midguts were incubated with pig anti-rabbit fluorescein isothiocyanate (FITC) conjugate $(10 \mu \mathrm{g} / \mathrm{ml}$; Nordic Immunological Laboratories BV, Tilburg, the Netherlands) for $1 \mathrm{~h}$ at room temperature. Finally, the specimens were mounted with CitiFluor (Agar Scientific Ltd., Stansted, England) and examined by UV microscopy (Leica Microsystems BV, Rijswijk, the Netherlands) at $\times 400$ magnification.

Total RNA extraction from plants and northern blot analysis. The presence of defective RNA molecules in TSWV isolates was demonstrated by northern blot analysis of total RNA extracts from $0.02 \mathrm{~g}$ of systemically infected leaves (8). Extracts were subjected to electrophoresis in a $1 \%$ agarose gel containing methylmercuric hydroxide and transferred onto a nylon membrane (Hybond $\mathrm{N}$; Amersham Pharmacia Biotech Benelux, Roosendaal, the Netherlands). The hybridization procedure was performed with a mixture of two distinct double-stranded DNA probes that were ${ }^{32} \mathrm{P}$-labeled by random priming. One probe was specific to the $5^{\prime}$ terminus (nucleotide positions 1 to 1,178 ) and the other to the $3^{\prime}$ terminus (nucleotide positions 7,749 to 8,897 ) of the reported viral complementary strand of TSWV L RNA (4).

Virus inoculation of primary cell culture system of $F$. occidentalis. To analyze whether the NL-04 env ${ }^{-}$isolate was able to infect thrips cells, purified virus preparations were inoculated to primary cell cultures of $F$. occidentalis. Purified preparations of the wt TSWV isolates BR-01 and NL-04 were used as controls. The primary cell cultures were prepared by crushing approximately 3-day-

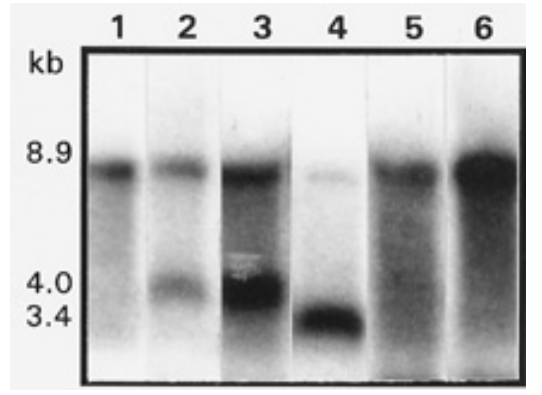

Fig. 1. Northern blot hybridization of a total RNA extract from infected $D a$ tura stramonium plants on which thrips acquired the Tomato spotted wilt virus (TSWV) isolates studied. Lane 1, BR-01 wild type (wt); lane 2, Pe-1; lane 3, Pe-1 transmitted by thrips; lane 4, defective interfering 16-2; lane 5, NL-04 wt; and lane 6, envelope-deficient NL-04. old thrips embryos and transplanting the tissue fragments into modified Kimura's insect medium $(13,19)$. Four-day-old cultures were overlayed with a purified virus suspension for $2 \mathrm{~h}$. The infectivity of the virus preparation when fresh and after $2 \mathrm{~h}$ of incubation, containing $10 \mu \mathrm{g}$ of virus per ml, was confirmed by mechanical inoculation to $C$. quinoa plants. Following this incubation, the cells were washed with a physiological salt solution, incubated in medium for $48 \mathrm{~h}$, and fixed with $3 \%$ paraformaldehyde- $0.1 \%$ glutaraldehyde. Infection of the cells was evaluated by immunofluorescent assay (19) using antibodies to the $\mathrm{N}$ and nonstructural $\left(\mathrm{NS}_{\mathrm{S}}\right)$ protein with a UV microscope (Leica Microsystems BV) at $\times 400$ magnification. These proteins are abundantly expressed in infected thrips cells $(25,31)$.

\section{RESULTS}

Titer of defective isolates in acquisition hosts. The amount of virus ingested may affect the transmission efficiency of the vector. Therefore, D. stramonium leaves infected with the isolates Pe-1, $16-2$, or env ${ }^{-}$with identical virus titers were used as a virus source in the transmission studies. These titers were determined on three leaf disks sampled at three different locations of each systemically infected leaf to be used. The mean ELISA values of these samples are shown in Table 1. The two wt (BR-01 and NL-04) and env ${ }^{-}$isolates reached similar titers in the leaves, while lower amounts of virus were found in the plants infected with isolates Pe-1 or 16-2.

Effect of defective viral RNAs on transmission. Isolates Pe-1 and 16-2, each containing a defective L RNA, were selected in view of their different virulence on plants $(8,10)$. Pe- 1 causes a stunting of $N$. rustica and D. stramonium plants and a mosaic or mottling on the systemically infected leaves followed by severe necrosis. These symptoms were indistinguishable in character and severity from those produced by wt virus (BR-01). The symptoms caused by $16-2$, however, were very mild, showing only a few necrotic spots on the inoculated leaves and a faint mottling on the systemically infected leaves, while no clear stunting was observed. Thus, 16-2 was characterized as a genuine DI isolate, whereas Pe-1 was not, as it did not cause clear symptom attenuation. Totally different results were obtained in the transmission experiments with these two defective isolates. Pe-1 was transmitted with an efficiency of $50.8 \%$, a level similar to that of the wt TSWV isolate BR-01 (53.1\%) (Table 1). On the other hand, isolate 16-2 was not transmitted at all. Remarkably, plants infected with isolate Pe-1 contained lower virus titers than those infected with 16-2 (Table 1). Since BR-01 and Pe-1 were transmitted with comparable efficiency, it can be concluded that the acquisition period given in this study suffices to exclude any effect of virus concentration in the leaves from which the thrips acquired the virus.

Northern blot hybridization was applied to detect intact and defective L RNAs in D. stramonium leaves used for virus acquisition and after transmission of Pe-1 by thrips. The amount of intact genomic L RNA of Pe-1 was considerably higher per gram of leaf material than that of 16-2-infected plants (Fig. 1, lane 2 versus lane 4), suggesting that the truncated RNA of Pe-1 did not strongly interfere with the replication of intact L RNA. On the other hand,

TABLE 1. Response of Datura stramonium plants to infection by different Tomato spotted wilt virus (TSWV) isolates and mutants and the rate at which these isolates were transmitted by the thrips Frankliniella occidentalis

\begin{tabular}{lcccc}
\hline TSWV & $\begin{array}{c}\text { Symptom } \\
\text { severity }\end{array}$ & $\begin{array}{c}\text { Mean enzyme-linked } \\
\text { immunosorbent assay value }\end{array}$ & $\begin{array}{c}\text { Transmission } \\
\text { rate }(\%)\end{array}$ & $n$ \\
\hline BR-01 wt & +++ & 1.26 & 53.1 & 64 \\
Pe-1 & +++ & 0.60 & 50.8 & 65 \\
DI 16-2 & + & 0.89 & 0 & 66 \\
& & 1.26 & 34.3 & 67 \\
NL-04 wt & +++ & 1.26 & 0 & 66 \\
NL-04 env & +++ & & & \\
\hline
\end{tabular}

${ }^{\mathrm{a}} \mathrm{wt}=$ Wild type, DI = defective interfering, and $\mathrm{env}^{-}=$envelope-deficient mutant. 
isolate 16-2 contained relatively high amounts of the defective $\mathrm{L}$ RNA, apparently suppressing the wt L RNA accumulation, and thus representing a true DI RNA.

Furthermore, it was verified whether the defective L RNA species of Pe-1 was transmitted along with its helper virus by thrips. Leaf disks inoculated by thrips were ground and mechanically inoculated to two D. stramonium plants. After 2 weeks, the presence of L RNA-specific fragments was analyzed in these plants by northern blotting (Fig. 1, lane 3), confirming thrips transmission of the defective RNA species of Pe-1.

Midgut infection by defective isolates Pe-1 and 16-2. Infection of the midgut epithelial cells is the first discernible sign of virus replication in the thrips to transmit tospoviruses as demonstrated by WMIS (18). Using this technique, larvae were analyzed for midgut infections after ingestion of the DI isolate 16-2, which could not be transmitted by thrips. Wild-type TSWV (BR-01) and the transmissible isolate Pe-1 were used as positive controls.

The first positive signals of wt TSWV infections were discerned by green-colored FITC spots in the epithelial cells in the anterior midgut region (Mg1) at $24 \mathrm{~h}$ pa (Fig. 2A, section 1). Subsequently, the virus migrates to the visceral circular and longitudinal muscle cells of this region within 72 to $96 \mathrm{~h}$ pa and, later on, to the muscle cells of the middle and posterior midgut regions $(\mathrm{Mg} 2$ and $\mathrm{Mg} 3$, respectively) (18). The visceral muscle tissue of the whole midgut of adults becomes infected, while the infection in the midgut epithelial cells appeared to be sloughed off after emergence of the adults (18).

To evaluate the infection of the midgut and muscle cells by these mutants and wt isolates, first instar larvae of $24 \mathrm{~h} \mathrm{pa}$, second instar larvae of 72 and $96 \mathrm{~h}$ pa, and 4-day-old adults were studied by WMIS. All larvae (100\%) that ingested wt TSWV (both BR-01 and NL-04) and Pe-1 showed clear signals of infection in the midgut, but only $23 \%$ of the larvae that ingested 16-2 showed infection. Besides the low number of infected larvae, 16-2 infections in the midgut were mild (Fig. 2A, section 3). The midgut infections were indexed by the proportion of the midgut epithelium, muscle cells, or both infected in thrips: 0 (no infection is found), 1 (faint infections restricted to the $\mathrm{Mg} 1$ region), 2 (heavy infections occur in $\mathrm{Mg} 1$ ), 3 (infections occur in both $\mathrm{Mg} 1$ and $\mathrm{Mg} 2$ ), and 4 (whole midgut is infected). The indexing results of 213 midguts (6 to 10 midguts per treatment) infected with any of the four TSWV isolates are given in Figure 3. The index values were slightly lower for Pe-1
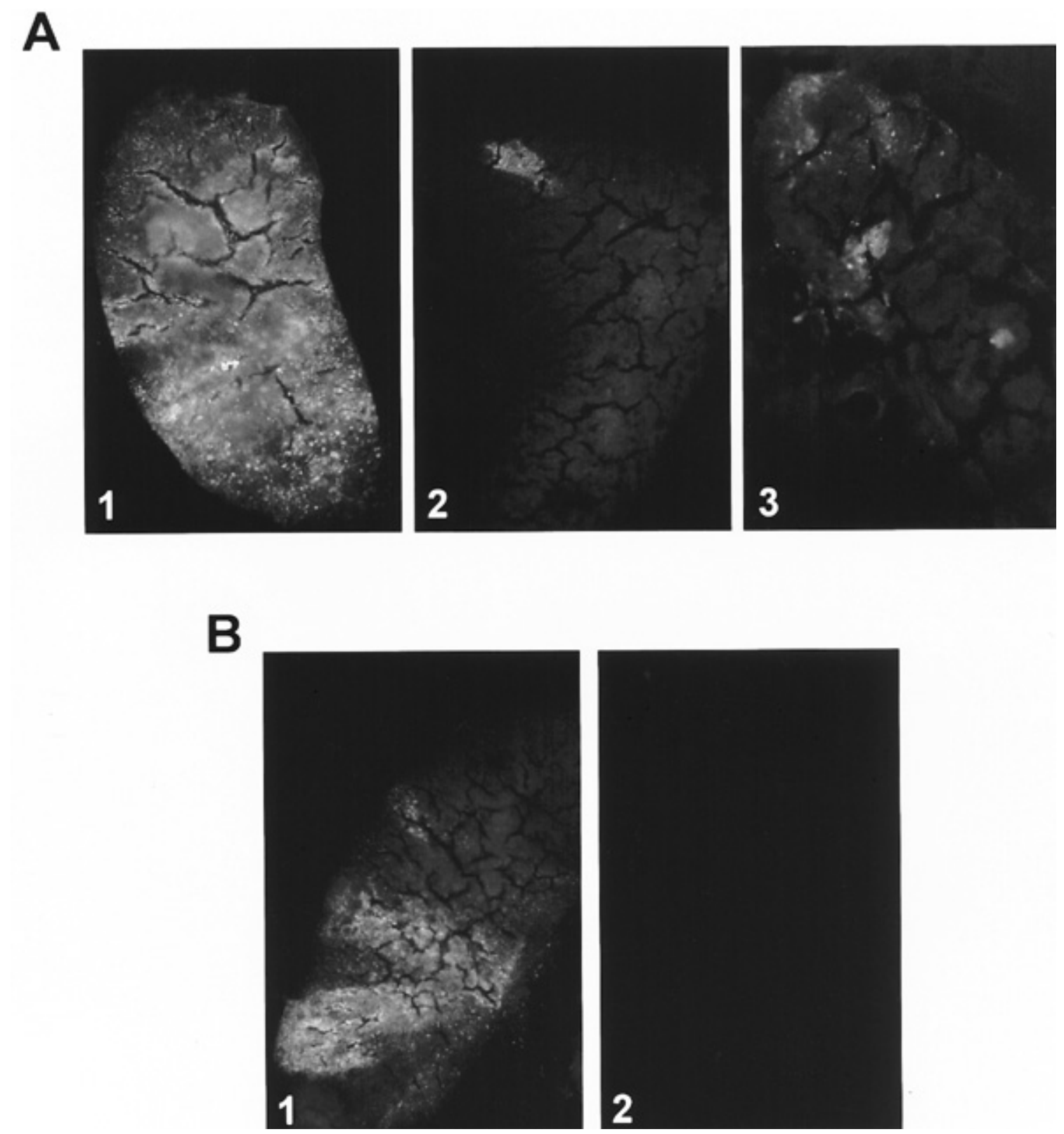

Fig. 2. Tomato spotted wilt virus infection of the midgut of thrips larvae $24 \mathrm{~h}$ postacquisition as demonstrated by whole mount immunofluorescent staining. A, Section 1, BR-01 wild type (wt); section 2, Pe-1; and section 3, defective interfering 16-2. B, Section 1, NL-04 wt; and section 2, envelope-deficient NL-04. 
than for wt virus (Fig. 3). Strong reactions were observed for both wt virus isolates in $\mathrm{Mg} 1$ and slightly less intensive signals for the Pe-1 isolate at $24 \mathrm{~h}$ pa (Fig. 2A, sections 2 and 3). The first signals of 16-2 were restricted to a limited number of small areas in $\mathrm{Mg} 1$. This index reached its maximum value in adults infected with the BR-01 and NL-04 wt isolates and Pe-1. With isolate 16-2, however, the infections remained restricted to a few small signals of a limited number of cells in the midgut of the larvae 72 and $96 \mathrm{~h}$ pa (Fig. 3). During all larval stages, the infection remained weak and was virtually absent in the midgut after emergence of the adults. Hence, the WMIS data show that the inability to transmit isolate $16-2$ can be explained by a restricted virus accumulation in the midgut.

Lack of viral membrane results in transmission deficiency. The env ${ }^{-}$isolate was used to test whether the envelope containing the viral glycoproteins was required for thrips transmission. Although the env ${ }^{-}$isolate reached nucleocapsid protein titers in the source plants comparable to those of wt virus (Table 1), the thrips exposed to this isolate were not able to transmit it. As this isolate was shown to be free of any defective RNAs (described above) (Fig. 1, lane 5), the reason for this transmission deficiency must have been due to the absence of an envelope containing the G1 and $\mathrm{G} 2$ proteins.

The env $v^{-}$mutant fails to infect the midgut and primary cell cultures of $\boldsymbol{F}$. occidentalis. To investigate whether the env $v^{-}$mutant was completely deficient in its capacity to infect the thrips, the midguts of thrips larvae, fed on env--infected hosts, were analyzed using WMIS. Signals of infection could not be discerned in the midgut of any thrips in their L1 and L2 stages or in their adult stage (Fig. 2B, section 2, and Fig. 3). To verify whether the env ${ }^{-}$mutant was completely unable to infect thrips cells, primary cell cultures derived from F. occidentalis (19) were inoculated with this isolate.

Infection of these cultures was monitored by detection of viral $\mathrm{N}$ and $\mathrm{NS}_{\mathrm{S}}$ proteins using FITC-labeled antibodies. None of the cells of six cultures inoculated with this isolate showed any sign of infection (Table 2; Fig. 4). Nucleocapsid preparations of wt BR-01, devoid of the envelope, also failed to infect the cell cultures. However, approximately 30 to $40 \%$ of cells in such cultures showed positive signals of infection when inoculated with preparations of complete virus particles of wt BR-01 and NL-04 as controls. The complete virus particles, nucleocapsid, and $\mathrm{env}^{-}$preparations were

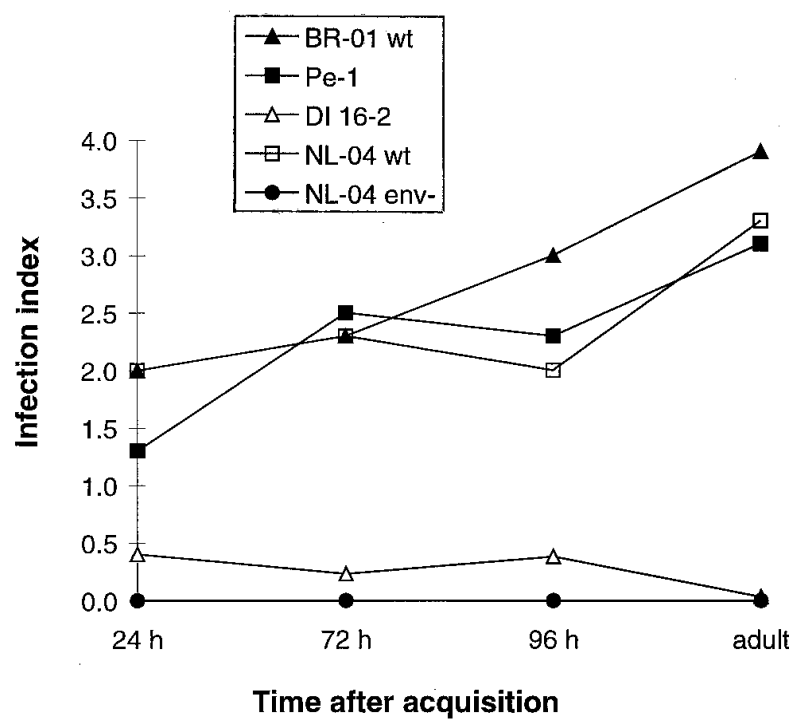

Fig. 3. Development of infection in the thrips midguts after acquisition of different Tomato spotted wilt virus isolates and mutants by newborn larvae as rated by the average infection index values in 24-, 72-, and 96-h-old larvae and 2-day-old adults. $0=$ No infections found, $1=$ faint infections restricted to the $\mathrm{Mg} 1$ region, 2 = heavy infections in $\mathrm{Mg} 1,3=$ infections in $\mathrm{Mg} 1$ and $\mathrm{Mg} 2$, and $4=$ whole midgut is infected. infectious, as could be demonstrated by mechanical inoculation to plants (Table 2). Hence, it is concluded from these results that the viral envelope contains the crucial determinants needed for virus entry into thrips cells. The absence of TSWV antigen in the midgut epithelium cells explains that the incompetence of the thrips to transmit the env $v^{-}$isolate is based on a complete failure of the env ${ }^{-}$ mutant to infect thrips tissues.

\section{DISCUSSION}

Neither infection of the midgut nor transmission to plants occurred when an env ${ }^{-}$isolate of TSWV was ingested from plants by thrips. This failure demonstrates that free nucleocapsids, the form of this isolate in plants, are not able to enter the midgut epithelial cells. This conclusion is confirmed by the results with primary cell cultures, which are a mixture of cells originating from various types of tissues or organs. The inability of nucleocapsids to infect thrips and cell cultures has to be explained by the absence of any domain or motif on the nucleocapsids to be recognized by receptors on the midgut epithelial cells and on cultured cells. Since the envelope is absent in both the nucleocapsid and env ${ }^{-}$inocula, it can be concluded that the receptor recognition sites occur on the viral envelope, i.e., on one or both viral glycoproteins. In analogy of the entry of animal viruses to their host cells, the G1 and G2 proteins of TSWV will possess the receptor binding sites, leading to endocytosis or membrane fusion of the virus with the cell and the release of nucleocapsids into the cytoplasm. Two thrips proteins of 94 and $50 \mathrm{kDa}$ have been reported as possible candidates as receptors for binding TSWV to thrips cells $(1,12)$.

The env ${ }^{-}$isolate, incapable of producing enveloped virus particles, as well as wt TSWV nucleocapsids failed to infect thrips as well as primary thrips cell cultures. Inocula of this isolate and the wt virus nucleocapsid preparations are highly infectious on plants. This feature indicates that the initial steps of the infection process in plants differ basically from that in thrips. Tentatively, it can be concluded that plants can be infected by tospovirus without the help of a receptor, whereas receptors are required to infect thrips.

Our results showed that a defective L RNA-containing isolate that causes wt-like symptoms (Pe-1) was efficiently transmitted, whereas a DI isolate (16-2) that produced attenuated symptoms on plants was not transmitted at all. The inability of thrips to transmit this DI RNA-containing isolate can be explained by the existence of a quantitative or dose-dependent barrier in the midgut or other tissues $(5,6)$. Comparing the amount of RNA detected on northern blots, it was concluded that the replication of the DI L RNA segment in isolate 16-2 strongly interferes with the replication of the wt L RNA species. As a consequence of this restricted replication of L RNA, inocula of this DI isolate will contain only low titers of infectious units compared with the wt and the defective L RNA-containing isolate (Pe-1) and, hence, can establish infections only in a low number of midgut cells. This conclusion is supported by the low levels of infection in the midgut after ingestion of this DI isolate. Northern blot analysis (Fig. 2, lanes 2 and 3) showed that the

TABLE 2. Infectivity of enveloped and nonenveloped Tomato spotted wilt virus (TSWV) preparations on primary cell cultures of Frankliniella occidentalis and Chenopodium quinoa leaves

\begin{tabular}{lccc}
\hline TSWV $^{\mathrm{a}}$ & $\mathrm{N}^{\mathrm{b}}$ & $\mathrm{NS}_{\mathrm{S}}{ }^{\mathrm{b}}$ & Local lesions $^{\mathrm{c}}$ \\
\hline NL-04 wt & + & + & 63 \\
NL-04 env & - & - & 117 \\
BR-01 wt & + & + & 42 \\
BR-01 RNP & - & - & 121 \\
\hline
\end{tabular}

${ }^{\mathrm{a}} \mathrm{wt}=$ Wild type, env $\mathrm{e}^{-}=$envelope-deficient mutant, and RNP = nucleocapsid preparation.

b Positive immunofluorescence reactions in primary cells with the antibodies to $\mathrm{N}$ and $\mathrm{NS}_{\mathrm{S}}$ proteins are marked with "+" and negative reactions with "-." c Number of local lesions formed 5 days after inoculation of the virus preparations on $C$. quinoa leaves. 
defective RNA species of isolate Pe-1 did not dramatically affect the replication of wt L RNA species. However, the slow start of Pe-1 accumulation in the midgut compared with wt infection implies that its multiplication is also slightly hampered or retarded.

The current study shows that thrips completely fail to transmit the DI isolate 16-2 despite limited initial replication in the midgut epithelium. On the other hand, Pe-1, which accumulated somewhat slower than wt, was transmitted at a rate similar to wt. These observations suggested that dose-dependent processes regulate the virus accumulation in the midgut. One of these processes may be the rate at which sufficient infectious units become available by replication in the midgut for further spread to other organs.

The moment at which the virus escapes from the midgut to infect the salivary glands has to be projected before pupation of the larvae. Pupation is characterized by a drastic renewal of the midgut epithelium $(5,6,11,14,16)$, which may cause an almost complete elimination of TSWV with the tissue sloughed off. The virus, which can be found in the midgut muscular tissues when the thrips be-
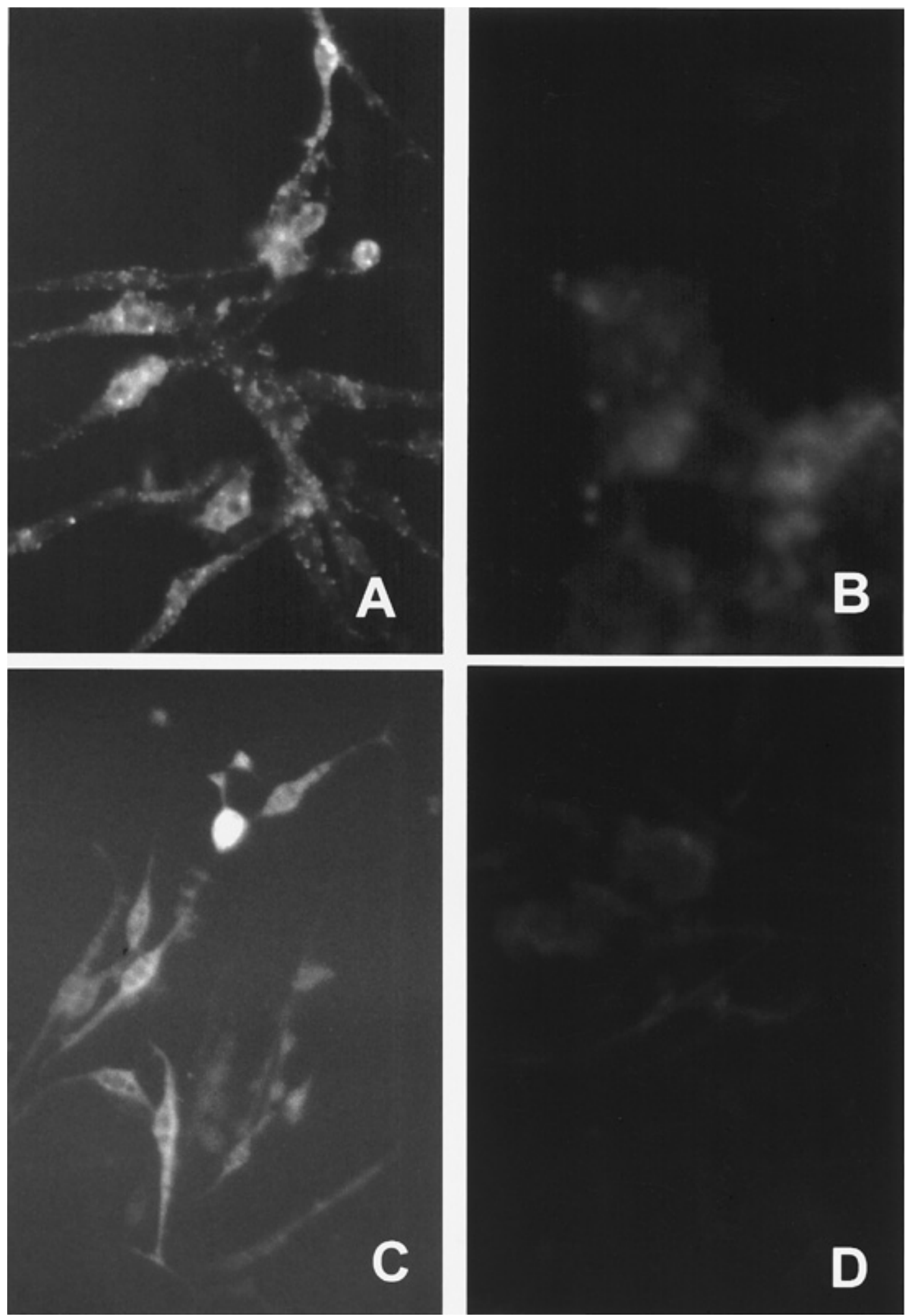

Fig. 4. Immunofluorescent staining of primary thrips cell cultures after infection with A and C, wild-type and B and D, envelope-deficient NL-04 isolates using antiserum to the $\mathbf{A}$ and $\mathbf{B}, \mathrm{N}$ and $\mathbf{C}$ and $\mathbf{D}, \mathrm{NS}_{\mathrm{S}}$ protein. 
come adult, has apparently overcome this abortive process by escaping from the midgut epithelia before pupation.

One of the possible factors of the dose-dependent midgut barrier may consist of digestive activities at the intracellular level, autophagolysis, as suggested by Ullman et al. $(24,26)$. Autophagy seemed to attack viral inclusions in the infected cells to remove them. However, the real role of this system for the intracellular digestion of viral proteins should be further elucidated.

The results in this study suggest that env ${ }^{-}$TSWV mutants, when they arise in naturally infected plants, will not spread, as the thrips fail to transmit them. Our studies also showed that the probability that DI RNAs will be spread after generation in a plant is small. They will, when acquired, be either eliminated or suppressed during the infection and circulation within the thrips due to the dosedependent effects of the midgut infection.

\section{LITERATURE CITED}

1. Bandla, M. D., Campbell, L. R., Ullman, D. E., and Sherwood, J. L. 1998. Interaction of tomato spotted wilt tospovirus (TSWV) glycoproteins with a thrips midgut protein, a potential cellular receptor for TSWV. Phytopathology 88:98-104.

2. De Ávila, A. C., De Haan, P., Kormelink, R., Resende, R. de O., Goldbach, R. W., and Peters, D. 1993. Classification of tospoviruses based on phylogeny of nucleoprotein gene sequences. J. Gen. Virol. 74:153-159.

3. De Ávila, A. C., Huguenot, C., Resende, R. de O., Kitajima, E. W., Goldbach, R. W., and Peters, D. 1990. Serological differentiation of 20 isolates of tomato spotted wilt virus. J. Gen. Virol. 71:2801-2807.

4. De Haan, P., Kormelink, R., Resende, R. de O., Van Poelwijk, F., Peters, D., and Goldbach, R. 1991. Tomato spotted wilt virus L RNA encodes a putative RNA polymerase. J. Gen. Virol. 72:2207-2216.

5. Hardy, J. L. 1988. Susceptibility and resistance of vector mosquitoes. Pages 87-126 in: The Arboviruses: Epidemic and Ecology. T. P. Monath, ed. CRC Press, Boca Raton, FL.

6. Hardy, J. L., Houk, E. J., Kramer, L. D., and Reeves, W. C. 1983. Intrinsic factors affecting vector competence of mosquitoes for arboviruses. Annu. Rev. Entomol. 28:229-262.

7. Ie, T. S. 1982. A sap-transmissible, defective form of tomato spotted wilt virus in plant cells. J. Gen. Virol. 59:387-391.

8. Inoue-Nagata, A. K., Kormelink, R., Nagata, T., Kitajima, E. W., Goldbach, R., and Peters, D. 1997. Effects of temperature and host on the generation of tomato spotted wilt virus defective interfering RNAs. Phytopathology 87:1168-1173.

9. Inoue-Nagata, A. K., Kormelink, R., Nagata, T., Kitajima, E. W., Goldbach, R., and Peters, D. 1997. How to avoid generation of defective interfering RNAs of tomato spotted wilt virus in greenhouses. (Abstr.) Fitopatol. Bras. 22:336.

10. Inoue-Nagata, A. K., Kormelink, R., Sgro, J.-Y., Nagata, T., Kitajima, E. W., Goldbach, R., and Peters, D. 1998. Molecular characterization of tomato spotted wilt virus defective interfering RNAs and detection of truncated L proteins. Virology 248:342-356.

11. Kaslow, D. C., and Welburn, S. 1997. Insect-transmitted pathogens in the insect midgut. Pages 432-462 in: Biology of the Insect Midgut. M. J. Lehane and P. F. Billingsley, eds. Chapman \& Hall, London.

12. Kikkert, M., Meurs, C., van de Wetering, F., Dorfmüller, S., Peters, D., Kormelink, R., and Goldbach, R. 1998. Binding of tomato spotted wilt virus to a $94-\mathrm{kDa}$ thrips protein. Phytopathology 88:63-69.
13. Kimura, I. 1986. A study of rice dwarf virus in vector cell monolayers by fluorescent antibody focus counting. J. Gen. Virol. 67:2119-2124.

14. Moritz, G. 1997. Structure, growth and development. Pages 15-63 in: Thrips as Crop Pest. T. Lewis, ed. CAB International, London.

15. Mound, L. A. 1996. The Thysanoptera vector species of tospovirus. Acta Hortic. 431:298-307.

16. Müller, K. 1926. Beiträge zur Biologie, Anatomie, Histologie und innern Metamorphose der Thripslarven. Z. Wiss. Zool. 130:252-302.

17. Murphy, F. A., Fauquet, C. M., Bishop, P. H. L., Ghabriel, S. A., Jarvis, A. W., Martelli, G. P., Mayo, M. A., and Summers, M. D. 1995. Virus taxonomy, sixth report of the International Committee on Taxonomy of Viruses. Arch. Virol. 10(suppl.):1-586.

18. Nagata, T., Inoue-Nagata, A. K., Smid, H., Goldbach, R., and Peters, D. 1999. Tissue tropism related to vector competence of Frankliniella occidentalis for tomato spotted wilt virus. J. Gen. Virol. 80:507-515.

19. Nagata, T., Storms, M. M. H., Goldbach, R., and Peters, D. 1997. Multiplication of tomato spotted wilt virus in primary cell cultures derived from two thrips species. Virus Res. 49:59-66.

20. Peters, D., Loomans, A., Nagata., T., Wijkamp, I., and van de Wetering, F. 1997. Methods to rear and maintain thrips in tospovirus transmission studies. Pages 152-159 in: Invertebrates in Captivity Conference, Tucson, AZ. SASI (Sonoran Arthropod Studies Institute), Tuscon, AZ.

21. Resende, R. de O., De Haan, P., De Ávila, A. C., Kitajima, E. W., Kormelink, R., Goldbach, R., and Peters, D. 1991. Generation of envelop and defective interfering RNA mutants of tomato spotted wilt virus by mechanical passage. J. Gen. Virol. 72:2375-2383.

22. Resende, R. de O., De Haan, P., Van de Vossen, E., De Ávila, A. C., Goldbach, R., and Peters, D. 1992. Defective interfering RNA segments of tomato spotted wilt virus retain both virus genome termini and have extensive internal deletions. J. Gen. Virol. 73:2509-2516.

23. Tashiro, H. 1967. Selfwatering acrylic cages for confining insects and mites on detached leaves. J. Econ. Entomol. 60:354-356.

24. Ullman, D. E., Cho, J. J., Mau, R. F. L., Westcot, D. M., and Custer, D. M. 1992. A midgut barrier to tomato spotted wilt virus acquisition by adult western flower thrips. Phytopathology 82:1333-1342.

25. Ullman, D. E., German, T. L., Sherwood, J. L., Westcot, D. M., and Cantone, F. A. 1993. Tospovirus replication in insect vector cells: Immunocytochemical evidence that the nonstructural protein encoded by the $S$ RNA of tomato spotted wilt tospovirus is present in thrips vector cells. Phytopathology 83:456-463.

26. Ullman, D. E., Westcot, D. M., Chenault, K. D., Sherwood, J. L., German, T. L., Bandla, M. D., Cantone, F. A., and Duer, H. L. 1995. Compartmentalization, intracellular transport, and autophagy of tomato spotted wilt tospovirus proteins in infected thrips cells. Phytopathology 85:644-654.

27. van de Wetering, F., Goldbach, R., and Peters, D. 1996. Tomato spotted wilt tospovirus ingestion by first instar larvae of Frankliniella occidentalis is a prerequisite for transmission. Phytopathology 86:900-905.

28. Webb, S., Tsai, J., and Forrest, M. 1998. Bionomics of Frankliniella bispinosa and its transmission of tomato spotted wilt virus. Page 67 in: 4th Int. Symp. on Tospovirus and Thrips in Floral and Vegetable Crops. Virology Department, Wageningen Agricultural University, Wageningen, the Netherlands.

29. Wijkamp, I., Almarza, N., Goldbach, R., and Peters, D. 1995. Distinct levels of specificity in thrips transmission of tospoviruses. Phytopathology 85:1069-1074.

30. Wijkamp, I., and Peters, D. 1993. Determination of the median latent period of two tospoviruses in Frankliniella occidentalis, using a novel leaf disk assay. Phytopathology 83:986-991.

31. Wijkamp, I., Van Lent, J., Kormelink, R., Goldbach, R., and Peters, D. 1993. Multiplication of tomato spotted wilt virus in its vector, Frankliniella occidentalis. J. Gen. Virol. 74:341-349. 